\title{
Adenocarcinoma with Neuroendocrine Differentiation
}

National Cancer Institute

\section{Source}

National Cancer Institute. Adenocarcinoma with Neuroendocrine Differentiation. NCI

Thesaurus. Code C66745.

An invasive adenocarcinoma characterized by the presence of focal or extensive neurosecretory cell differentiation with the formation of organoid patterns. 